\title{
TOPOGRAPHYC SHADOW INFLUENCE ON OPTICAL IMAGE ACQUIRED BY SATELLITE IN THE SOUTHERN HEMISPHERE ${ }^{1}$
}

\author{
Michelle M. França ${ }^{2 *}$, Elpidio I. Fernandes Filho ${ }^{3}$, Williams P. M. Ferreira ${ }^{4}$, João L. Lani ${ }^{3}$, \\ Vicente P. Soares ${ }^{3}$
}

\author{
${ }^{2 *}$ Corresponding author. Universidade Tecnológica Federal do Paraná - UTFPR/ Francisco Beltrão, Brasil. \\ E-mail: michellem@utfpr.edu.br
}

\section{KEYWORDS}

landsat, remote sensing, solar radiation.

\begin{abstract}
During image acquisition, is usually chosen scenes with a lesser cloud cover to avoid loss of spectral information. However, when training samples are collected for image classification, the user finds shadowed areas. Such situation is similar to the presence of clouds since spectral information of these classes is the same in all optical bands of the sensor. This fact becomes more pronounced in mountainous relief areas due to shadow projection on the terrain, which can vary among all seasons during the solar year. With the goal to obtain images with a lower presence of shadow, it was simulated, under the same relief conditions, shading variation in function of latitude $\left(0^{\circ}\right.$ to $\left.40^{\circ} \mathrm{S}\right)$. Solar radiation models were processed for the days and times passages of the Landsat TM and ETM+ satellite on the Southern Hemisphere. It was verified that over $30^{\circ} \mathrm{S}$ and $40^{\circ} \mathrm{S}$ latitudes, a loss of shading area varying between $27 \%$ to $91 \%$ and that images should be preferentially taken between October and February. For latitudes comprising $0^{\circ}$ and $10^{\circ}$ $\mathrm{S}$, the loss was considered negligible, when we set a $10 \%$ threshold of loss in the total valid area in an image. According to the amount of radiation in a terrain, South and West areas received less direct solar radiation over the year for all analyzed latitudes in the modeling.
\end{abstract}

\section{INTRODUCTION}

The distortions of a radiance measured by sensors are common to image acquisition process and could affect the quality of satellite images (Zhang et al., 2015). The topography also can affect the radiometric properties of these data. The estimation of land use cover on complex topography creates unique challenges compared to vegetation cover on flat terrain (Ediriweera et al., 2013).

Mountainous ecosystems are characterized by the presence of changes in the land use and cover determined by the altitude gradient and slope, reflecting the biophysical conditions of the objects on the Earth's surface. The topography influences solar irradiance measured in these areas and can produce biophysics variations such as the vigor of vegetation on relatively short areas (Lambin \& Meyfroidt, 2011).
The slope and the aspect on a terrain surface may also change received insolation measured altering the radiance by a sensor, decreasing precision in a specific classification of land use cover (Balthazar et al., 2012; Vanonckelen et al., 2013). Such effect is more evident in mountainous areas.

Some authors have described algorithms for atmospheric and radiometric correction in satellite (Gao et al., 2009; Schanmugan, 2012; Goyens et al., 2013). Many authors have developed algorithms to detect and remove shadows aiming to improve the final accuracy of orbital images of supervised classification (Sanin et al., 2012; Filippi \& Güneralp, 2013; Movia et al., 2016). But there are still few studies about correction of topographic illumination because of the algorithms area hard to generalized and not automatically applicable (Hantson \&

\footnotetext{
${ }^{1}$ Part of the doctoral thesis of the first author.

${ }^{3}$ Universidade Federal de Viçosa/ Viçosa - MG, Brasil.

${ }^{4}$ Embrapa Café/ Viçosa - MG, Brasil.

Received in: 9-6-2016

Accepted in: 7-12-2018
} 
Chuvieco, 2011). Therefore, this method can imply severe influence on quantitative approaches that are dependent on the targets spectral characterization (Ponzoni, 2016).

Topography shadows in mountainous terrain may confound trend-based forest change detection approaches (Chance et al., 2016). Thus, it is important to choose suitable seasons for orbital sensor data acquirement, to maximize the use of satellite image in these areas (França et al., 2014).

The spectral information bellow topography shadows are likely to be lost on satellite images because the real reflectance cannot be recovered consists in a problem of mountainous areas because the total irradiation at the surface is a combination of diffuse irradiation and terrain reflected irradiation from nearby slopes (Shulmann et al., 2015). Although widely accepted that topographic surface orientation has an influence on terrain insolation, little is discussed on how declivity influences topographic shading in function of year season.
In this context, the aim of this study was to determinate the better season of the year for the acquisition of satellite images in the Southern Hemisphere, taking into account areas with the same geomorphological structure, varying only the latitude. The conditions concerning the influence of the solar exposures faces and the slope in the terrain shading were also evaluated.

\section{MATERIAL AND METHODS}

The study area is the Benevente River Hydrographic Basin with $1,090 \mathrm{~km}^{2}$ of drainage area and $240 \mathrm{~km}$ of perimeter. It is located in the Southern of the State of Espírito Santo including Alfredo Chaves Anchieta, Guarapari, Iconha and Piúma municipalities. This area is geographically located between $40^{\circ} 33^{\prime}$ and $41^{\circ} 00^{\prime}$ west meridians and $20^{\circ} 26^{\prime}$ and $20^{\circ} 49^{\prime}$ south parallels. This area was chosen for present a large variability of reliefs, such as beaches and mountains (figure 1).

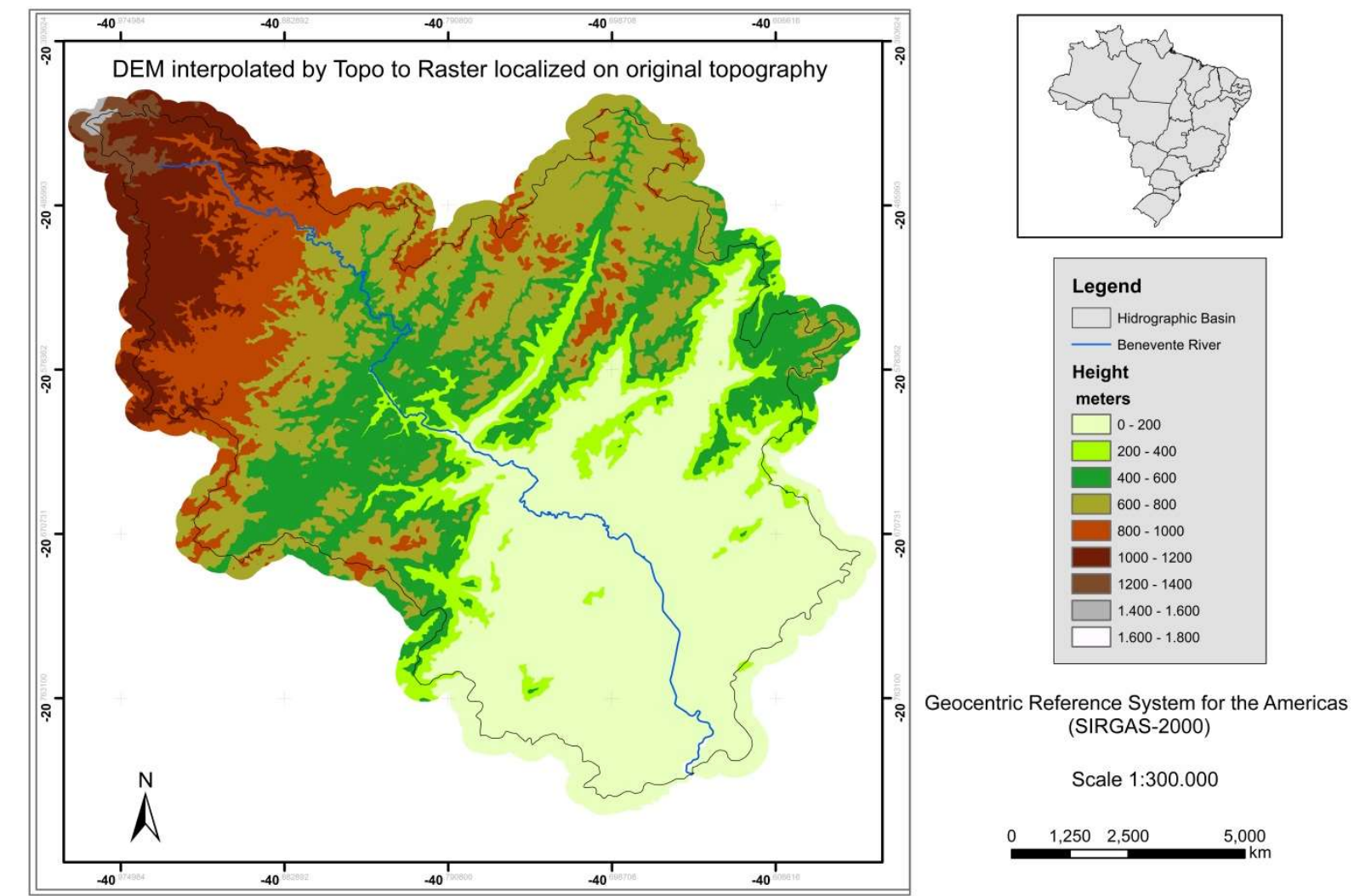

Source: Brazilian Institute of Geography and Statistica, 1973.

Shuttle Radar Topographic Mission, Nasa, 2000.

FIGURE 1. Study Area - The Benevente river basin, in its original location.

The flow chart methodology employed can be checked in figure 2. The Digital Elevation Model (DEM) was obtained on The CGIAR Consortium for Spatial Information (Jarvis et al., 2008) with the spatial resolution of $90 \mathrm{~m}$, from the elevation data from the Shuttle Radar Topographic Mission (SRTM). Terrain data were extracted from "Spatial Analyst" and "Solar Analyst" on the ArcGIS software modules (ESRI, 2011).
The DEM (SRTM) consists in a mapping obtained through interferometry using radar data with $\mathrm{C}$ band (Farr \& Kobrick, 2000). SRTM data were submitted to preprocessing operations to remove flaws and spurious pits (adapted from Valeriano, 2004). After MDE correction, interpolation was performed using Topo to raster procedure (Hutchinson, 1989). 

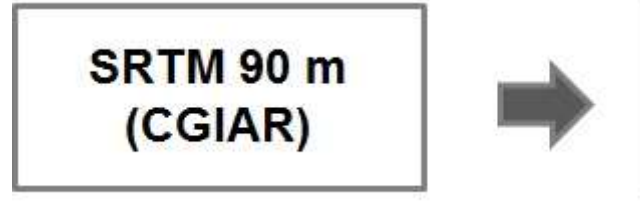
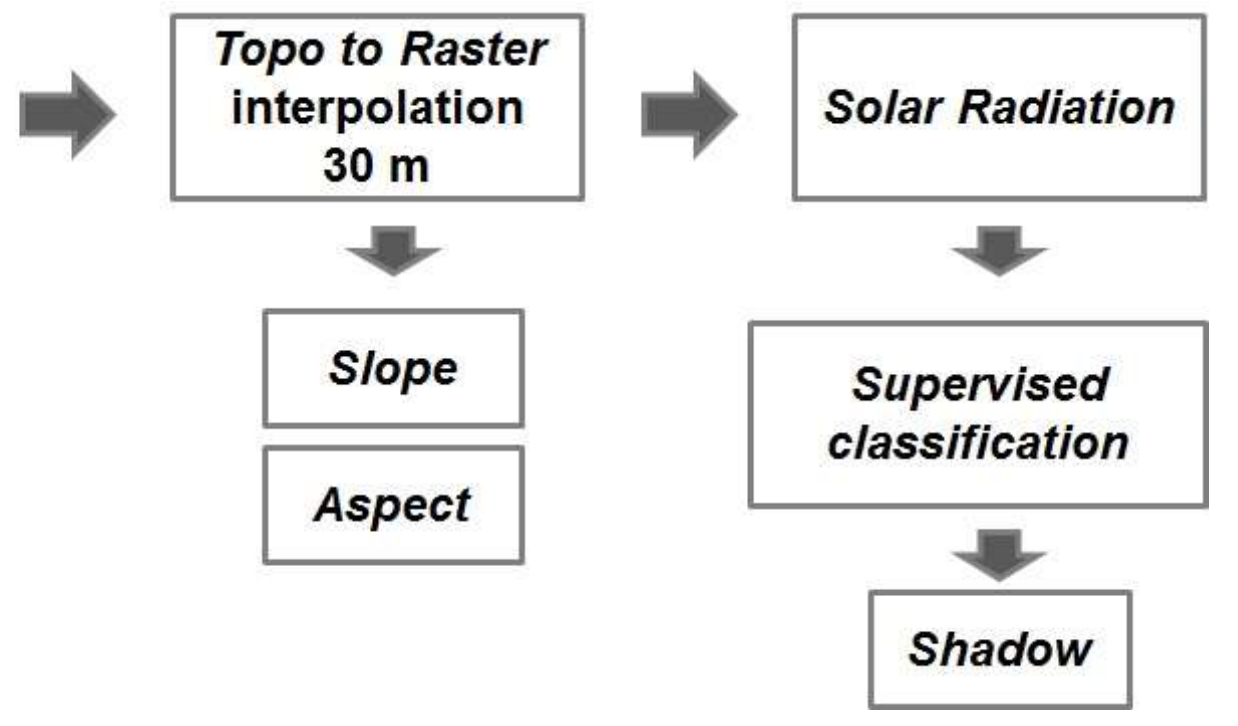

\section{Topo to Raster interpolation $30 \mathrm{~m}$}

FIGURE 2. Flowchart containing methodology applied in the MDE to extract the terrain data.

Interpolation procedure developed by Hutchinson et al., (2009) is calculated through the sum of residues square, using elevation data, represented by $\mathrm{Z}_{\mathrm{est}}\left(\mathrm{l}_{\mathrm{i}}\right)$ from every $\left(\mathrm{x}_{\mathrm{i}}, \mathrm{yi}\right)$, as given by [eq. (1)]:

$$
\mathrm{Z}_{\mathrm{i}}=\mathrm{f}\left(\mathrm{x}_{\mathrm{i}}, \mathrm{y}_{\mathrm{i}}\right)+\mathrm{E}_{\mathrm{i}} \quad \mathrm{i}=1, \ldots, \mathrm{n}
$$

Where,

$\mathrm{Z}_{\mathrm{i}}$ is an elevation data value at location $\mathrm{x}_{\mathrm{i}}, \mathrm{y}_{\mathrm{i}}$;

$\mathrm{f}$ is a smoothing function,

$\mathrm{n}$ is the number of data points and $\varepsilon$ is a zero mean error term with standard deviation $\mathrm{w}_{\mathrm{i}}$.

Assuming all sampled points are randomly located on the grid, a standard deviation is given by [eq. (2)]:

$$
\mathrm{w}_{\mathrm{i}}=\mathrm{hs}_{\mathrm{i}} / \sqrt{ } 12
$$

Where,

$\mathrm{h}$ corresponds to grid spacement, and

$\mathrm{S}_{\mathrm{i}}$ is the slope of the grid cell associated with the $i^{\text {th }}$ data point.

Function $\mathrm{f}$ can be estimated by solving for the regular grid finite difference approximation to the bivariate function $f$ that minimizes by [eq. (3)]:

$$
\sum_{i=l, n}\left[\left(z_{i}-f\left(x_{i}, y_{i}\right)\right) / w_{i}\right]^{2}+\lambda \mathrm{J}(f)
$$

Where,
$\mathrm{J}(\mathrm{f})$ representing $f$ is a measure of the roughness of the function $f$ regarding first and second derivatives and,

$\lambda$ is a positive number for the smoothing parameter, normally chosen that the weighted residual sum of squares in [eq. (3)].

The DEM was solar radiation model, and this modeling was made for the day and time of the satellite passage used to generate the direct the central area latitude.

The comparison during modeling, the latitude geographical coordinate in the central area, was altered aiming to simulate the effect of the shading in different latitudes, and the quantitative impact related to the useful loss area in images. In this way whereas the modeling of solar radiation has the latitude of the center of the area as one of its most important variables, simulations were made in this study considering latitudes $0^{\circ} ; 10^{\circ} \mathrm{S} ; 20^{\circ} \mathrm{S} ; 30^{\circ} \mathrm{S}$ and $40^{\circ} \mathrm{S}$, which produced as a result 100 images with direct solar radiation (Dirtot) received by the terrain (20 dates scenes $x 5$ latitudes) in the same relief.

The incidence of the direct and diffuse global solar radiation was obtained by Solar Analyst module, of the ArcGIS software, taking into consideration the dates and schedules (12:38 PM, local time) of TM and ETM + Landsat satellites transit in the year of 2011 according to Table 1 . 
TABLE 1. Landsat satellite transit dates during the year 2011 (available in the USGS collection).

\begin{tabular}{ccccc}
\hline Scene Date & Satellite & Sun Azimuth $\left(^{\circ}\right)$ & Sun Elevation $\left(^{\circ}\right)$ & Cloud Cover $(\%)$ \\
\hline $01 / 18 / 2011$ & ETM+ & 96,6651 & 58,0117 & 50 \\
$02 / 03 / 2011$ & ETM+ & 89,5345 & 56,6248 & 40 \\
$02 / 19 / 2011$ & ETM+ & 80,5173 & 55,2210 & 40 \\
$04 / 08 / 2011$ & ETM+ & 52,1820 & 48,2417 & 90 \\
$04 / 16 / 2011$ & TM & 49,4779 & 45,9384 & 50 \\
$04 / 24 / 2011$ & ETM+ & 45,3446 & 44,9422 & 25 \\
$05 / 02 / 2011$ & TM & 43,6747 & 42,6424 & 40 \\
$05 / 10 / 2011$ & ETM+ & 40,5733 & 41,6542 & 50 \\
$05 / 18 / 2011$ & TM & 39,9125 & 39,5719 & 25 \\
$05 / 26 / 2011$ & ETM+ & 37,8322 & 38,8369 & 0 \\
$06 / 19 / 2011$ & TM & 37,9663 & 36,8164 & 10 \\
$06 / 27 / 2011$ & ETM+ & 37,4854 & 36,2524 & 70 \\
$07 / 13 / 2011$ & ETM+ & 39,2629 & 37,0152 & 1 \\
$07 / 29 / 2011$ & ETM+ & 41,9794 & 39,2303 & 5 \\
$08 / 14 / 2011$ & ETM+ & 45,5064 & 42,7364 & 0 \\
$09 / 07 / 2011$ & TM & 53,7314 & 48,7522 & 40 \\
$09 / 15 / 2011$ & ETM+ & 55,5009 & 52,1377 & 90 \\
$09 / 23 / 2011$ & TM & 60,1197 & 53,6023 & 45 \\
$10 / 09 / 2011$ & TM & 68,2981 & 57,9230 & 55 \\
$11 / 10 / 2011$ & TM & 88,4260 & 62,3773 & 70 \\
\hline
\end{tabular}

ETM+= Landsat Enhanced Thematic Mapper; TM= Landsat Thematic Mapper; WRS Path =216; WRS Row $=074$.

The total amount of radiation calculated for a particular location or area is given as global radiation. The calculation of direct, diffuse, and global insolation are repeated for each feature location or every location on the topographic surface, producing insolation maps for an entire geographic area.

Solar radiation data were generated through a mathematic model implemented on ArcGis 10.1 software according to Solar Analyst algorithm developed by Rich (1990) and Rich et al. (1994) and afterward modified by Rich \& Fu (2000).

A solar radiation simulation was obtained on an original surface for different latitudes, so we were able to compare radiation incidence on the same type of topography, varying only its latitude.

The algorithm employed to obtain the amount of solar radiation that reaches terrain was Radiation, it was calculated for every latitude, starting off its geographic coordinate of the central point and a single DEM.

Global radiation is the sum of direct and diffuse radiation of celestial and solar map sectors that could be calculated in an algorithm according to [eq. (4)]:

$$
\text { Global }_{\text {tot }}=\text { Dir }_{\text {tot }}+\text { Dif }_{\text {tot }}
$$

The direct radiation for a ground location is the sum of direct insolation $(\operatorname{Dir} \theta, \alpha)$ of all sunmap sectors, as shown in [eq. (5)]:

$$
\operatorname{Dir}_{\text {tot }}=\Sigma \operatorname{Dir}_{\theta, \alpha}
$$

The direct radiation of a sunmap sector $\left(\operatorname{Dir}_{\theta, \alpha}\right)$ with a centroid at zenith angle $(\theta)$ and azimuth angle $(\alpha)$ was obtained through [eq. (6)]:

$\operatorname{Dir}_{\theta, \alpha}=$ SConst $* \tau^{\mathrm{m}(\theta)} * \operatorname{SunDur}_{\theta, \alpha} * \operatorname{SunGap}_{\theta, \alpha} *$ $\cos \left(\operatorname{AngIn} \operatorname{In}_{\theta, \alpha}\right)$

Where,

SConst is the solar flux outside the atmosphere at the mean earth-sun distance, known as solar constant; $\tau$ is average transmissivity of atmosphere for the shortest path direction of the zenith;

$\mathrm{m}(\theta)$ is the relative optic length measured as a relative proportion to the zenith path length, according to [eq. (7)];

SunDur $_{\theta, \alpha}$ is the time duration represented by the sky sector;

SunGap $_{\theta, \alpha}$ is the gap fraction for the sunmap sector;

AngIn $n_{\theta, \alpha}$ is the angle of incidence between sky sector and the normal axis to the surface, according to [eq. (8)].

Relative optic length $m(\theta)$ was determined from solar zenith angle and elevation above sea level as given by [eq. (7)]:

$$
\mathrm{m}(\theta)=\exp \left(-0.000118 * \mathrm{ELEV}-1.638 * 10^{-9} * \mathrm{ELEV}^{2}\right) / \cos (\theta)
$$

Where,

$\theta$ is the solar zenith angle and ELEV is elevation above sea level in meters.

The surface effect orientation is obtained by multiplication of cosine of the angle of incidence $\left(\right.$ AngIn $\left.{ }_{\theta, \alpha}\right)$ between the intercepting surface and a given sky sector with a centroid at zenith angle $(\theta)$ and azimuth angle $(\alpha)$. It is obtained with [eq. (8)]:

$$
\text { AngIn } \theta, \alpha=\operatorname{acos}[\operatorname{Cos}(\theta) * \operatorname{Cos}(\mathrm{Gz})+\operatorname{Sin}(\theta) * \operatorname{Sin}(\mathrm{Gz}) * \operatorname{Cos}(\alpha-\mathrm{Ga})]
$$

Where,

$\mathrm{Gz}$ is the surface zenith angle and $\mathrm{Ga}$ is the surface azimuth angle.

For every sky sector, the diffuse radiation at its centroid was calculated, integrated over a time interval and 
corrected by the gap fraction and angle of incidence, as given by [eq. (9)]:

$$
\operatorname{Dif}_{\theta, \alpha}=\mathrm{R}_{\mathrm{glb}} * \mathrm{P}_{\mathrm{dif}} * \operatorname{Dur}^{*} \operatorname{SkyGap}_{\theta, \alpha} * \mathrm{Weight}_{\theta, \alpha} * \cos \left(\operatorname{AngIn}_{\theta, \alpha}\right)
$$

Where,

$\mathrm{R}_{\mathrm{glb}}$ is the normal global radiation (equation 10);

$\mathrm{P}_{\text {dif }}$ is the proportion of global normal radiation flux that is diffused;

Dur is the time interval of the analysis;

SkyGap $_{\theta, \alpha}$ is the gap fraction for the sky sector;

Weight $_{\theta, \alpha}$ is proportion of diffuse radiation originated in a given sky sector (equations 11 and 12);

AngIn $n_{\theta, \alpha}$ is the angle of incidence between the centroid of the sky sector and intercepting surface.

The normal global radiation $\left(\mathrm{R}_{\mathrm{glb}}\right)$ can be calculated with the sum of direct radiation from every sector, including obstructed sectors, without correction for the angle of incidence and the correcting of proportion of direct radiation $\left(1-\mathrm{P}_{\mathrm{dif}}\right)$.

$$
\mathrm{R}_{\mathrm{glb}}=\left(\operatorname{SConst} \Sigma\left(\tau^{\mathrm{m}(\theta)}\right)\right) /\left(1-\mathrm{P}_{\mathrm{dif}}\right)
$$

For the uniform sky diffuse model, Weight ${ }_{\theta, \alpha}$ was calculated based on Rich (1990):

$$
\text { Weight }_{\theta, \alpha}=\left(\cos \theta_{2}-\cos \theta_{1}\right) / \mathrm{DIV}_{\mathrm{azi}}
$$

Where,

$\theta 1$ and $\theta 2$ are boulding zenith angles of the sky sector,

DIV $_{\text {azi }}$ is the number of azimuthal divisions in the skymap.

For the standard overcast sky model, Weight ${ }_{\theta, \alpha}$ was evaluated as follows:

$$
\text { Weight }_{\theta, \alpha}=\left(2 \cos \theta_{2}+\cos 2 \theta_{2}-2 \cos \theta_{1}-\cos 2 \theta_{1}\right) / 4 * \mathrm{DIV}_{\mathrm{azi}}
$$

Thus, the diffuse solar radiation (Diftot) for the location was calculated as the sum of the diffuse solar radiation (Dif) from all the skymap sectors:

$$
\operatorname{Dif}_{\text {tot }}=\Sigma \operatorname{Dif}_{, \alpha}
$$

The aspect identifies the compass direction that the downhill slope faces for each location (Burrough \& McDonnell, 1998). The values on the output raster indicate the compass direction the surface faces at the location. The aspect is measured of clockwise in degrees from 0 (north face) to 360 (again north face) coming full circle. Flat areas have no downslope direction area given a value $-1^{\circ}$.

Five main orientation faces to the exhibition were used: flat, north, east, south and west (Table 2). Assuming a $3 \times 3$ matrix grid, as on the example below, algorithm uses $\mathrm{x}, \mathrm{y}$ and $\mathrm{z}$ (latitude, longitude and elevation respectively) parameters of eight neighboring cells from the center cell (e):

$$
\begin{array}{lll}
a & b & c \\
d & e & f \\
g & h & i
\end{array}
$$

In this way, $\mathrm{x}$ direction, in every cell is calculated by [eq. (14)]:

$$
[\mathrm{dz} / \mathrm{dx}]=((\mathrm{c}+2 \mathrm{f}+\mathrm{i})-(\mathrm{a}+2 \mathrm{~d}+\mathrm{g})) / 8
$$
[eq. (15)]:

In y direction, every cell was calculated with

$$
[\mathrm{dz} / \mathrm{dy}]=((\mathrm{g}+2 \mathrm{~h}+\mathrm{i})-(\mathrm{a}+2 \mathrm{~b}+\mathrm{c})) / 8
$$

The aspect can be implemented by the following algorithm:

$$
\operatorname{aspect}=57.29578 * \arctan ^{2}([\mathrm{dz} / \mathrm{dy}]-[\mathrm{dz} / \mathrm{dx}])
$$

Aspect was later converted to the compass eight directions (North, South, East, West, Southwest, Southeast, Northwest and Northeast) and with practicity purpose were again converted to all four main directions (Table 2).

TABLE 2. Classification of the main faces of orientation to solar exposure linked to quadrants represented by geographical angle coordinates.

\begin{tabular}{ccccc}
\hline Previous position & Angle & Radiation direction & ID - Class & ID - Reclassified \\
\hline Plan & -1 & Plan & 1 & 0 \\
NW, N and NE & $315^{\circ}-45^{\circ}$ & North & 2 & 1 \\
NE, E and SE & $45^{\circ}-135^{\circ}$ & East & 4 & 2 \\
SE, S and SW & $135^{\circ}-225^{\circ}$ & South & 6 & 3 \\
SW, W and NW & $225^{\circ}-315^{\circ}$ & West & 8 & 4 \\
\hline
\end{tabular}

$\mathrm{N}=$ North; NE = Northeast; $\mathrm{E}=$ East; NW = Northwest; $\mathrm{S}=$ South; $\mathrm{SE}=$ Southeast; $\mathrm{W}=$ West; $\mathrm{SW}=$ Southwest.

Supervised classification was used by the maximum likelihood algorithm (Maxver) of the thematic image from Landsat TM sensor 05/31/2010, 216 orbits, with the combination of bands 3,4 and 5 contained spectral bands red $(0,63-0,69 \mu \mathrm{m})$, shortwave infrared $(0,76-0,90 \mu \mathrm{m})$ and near-infrared $(1,55-175 \mu \mathrm{m})$. The chosen combination presented the highest kappa accuracy index $(\mathrm{k}=0.91)$, among the tested set.
Such procedure was conducted to map the image areas that showed topography shade. With the tabulate Area Command available in the Spatial Analyst module of the ArcGis software, area information and descriptive statistics of each pixel of raster images of the slope and aspect were extracted. Thus, the quantities of radiation incident on each class of slope and aspect, which are presented in figures 4 and 5, were obtained. 
Thus, it was set the selection of a scene obtained in the winter-time image, when the degree of luminosity decreases, making those periods opportune to the separation of the relief shadows.

The Dirtot was overlaid to the image area classified as "shadow" for obtaining the average value of this variable. Dirtot data were reclassified in two intervals, shadow (class 1) and other (class 2). Such processing was performed for the five latitudes considered in this study.

To obtain the amount of Dirtot, a cross-tabulation with the ArcGis Spatial Analyst module was again performed to extract the amount of radiation incident on the different slopes. The data were transformed into percentage and was used the same principle on the aspect i.e. the images containing the Dirtot were overlaid to the "aspect" file and tabulated, allowing identifying the faces who received higher or lower incidence of Dirtot depending on the latitude.
The radiation was also quantified in the slope, from images with an approximate date to the dates of the equinoxes and solstices. For this step, only the latitudes $0^{\circ}$, $20^{\circ} \mathrm{S}$ and $40^{\circ} \mathrm{S}$ were taken into account and slope classes according to Embrapa recommendation (1999) in 0-3\% (flat), 3-8\% (gently undulating), 8-20\% (undulating), 20$45 \%$ (rolling), $45-75 \%$ (moderately steep) and $>75 \%$ (steep).

\section{RESULTS AND DISCUSSION}

The maximum values of the Dirtot in $\mathrm{MJ} \mathrm{m}^{-2}$ obtained from approximated solstices and equinoxes dates in the Landsat images can be observed in Table 3.

Along the year, it was observed that the shading occurred mainly in the period from May to August, when the lowest Dirtot was recorded during the winter solstice in the Southern hemisphere. The Dirtot for latitude $40^{\circ} \mathrm{S}$ corresponded on average to $35 \%$ of the estimated value for the same terrain situated at latitude $0^{\circ}$ (Equator).

TABLE 3. Maximum amounts of direct solar radiation $\left(\mathrm{MJ} \mathrm{m}^{-2}\right)$ on different dates of satellite transit and latitudes of the Southern Hemisphere for 11:30 AM - 12:30 AM local time.

\begin{tabular}{|c|c|c|c|c|c|}
\hline \multirow[t]{2}{*}{ Date } & \multicolumn{5}{|c|}{ Latitude } \\
\hline & $\mathbf{0 0 ^ { \circ }}$ & $10^{\circ} \mathrm{S}$ & $20^{\circ} \mathrm{S}$ & $30^{\circ} \mathrm{S}$ & $40^{\circ} \mathrm{S}$ \\
\hline Jan $18^{\text {th }} \mathrm{SS}$ & 2.43 & 2.55 & 2.60 & 2.59 & 2.48 \\
\hline Apr $08^{\text {th }} \mathrm{AE}$ & 2.54 & 2.45 & 2.58 & 2.06 & 1.73 \\
\hline Jun $19^{\text {th }}$ WS & 2.33 & 2.14 & 1.84 & 1.42 & 0.82 \\
\hline Sep $23^{\text {rd }} \mathrm{SE}$ & 2.55 & 2.54 & 2.43 & 2.25 & 2.01 \\
\hline
\end{tabular}

$\mathrm{SS}=$ Summer solstice; $\mathrm{AE}=$ Autumn equinox; $\mathrm{WS}=$ Winter Solstice and $\mathrm{SE}=$ Spring equinox.

The solar radiation obtained was plotted in a graphic with latitudes $0^{\circ}$ to $40^{\circ}$ in Southern Hemisphere (Figure 3), when was possible to find a percentage of shadowed areas. The effect of shading of the Southern and Western exposed faces of the relief influences the satellite images in the mountainous areas in the southern hemisphere. This fact causes loss of information about the correct proportion of the classes' distribution of use/cover of land. A similar result to this pattern of curves was presented by Koudouris et al. (2017) in Athens, North Hemisphere comparing the amount of incident radiation for a historical series of 12 years.
The prevalence of major topography shadow was more pronounced for the latitude $40^{\circ} \mathrm{S}$, in which there was $91 \%$ of shadow coverage. This fact occurred on a date close to the winter solstice, on 06/19/2011. At this time of the year, the sun is farther from the Equator, with direct incidence on the Tropic of Cancer, and the solar elevation angle reaches minimum values characterizing the winter solstice in the Southern Hemisphere, causing greater shading in places that present mountainous relief (Holben \& Justice, 1980; Hantson \& Chuvieco, 2011; López et al., 2014). 


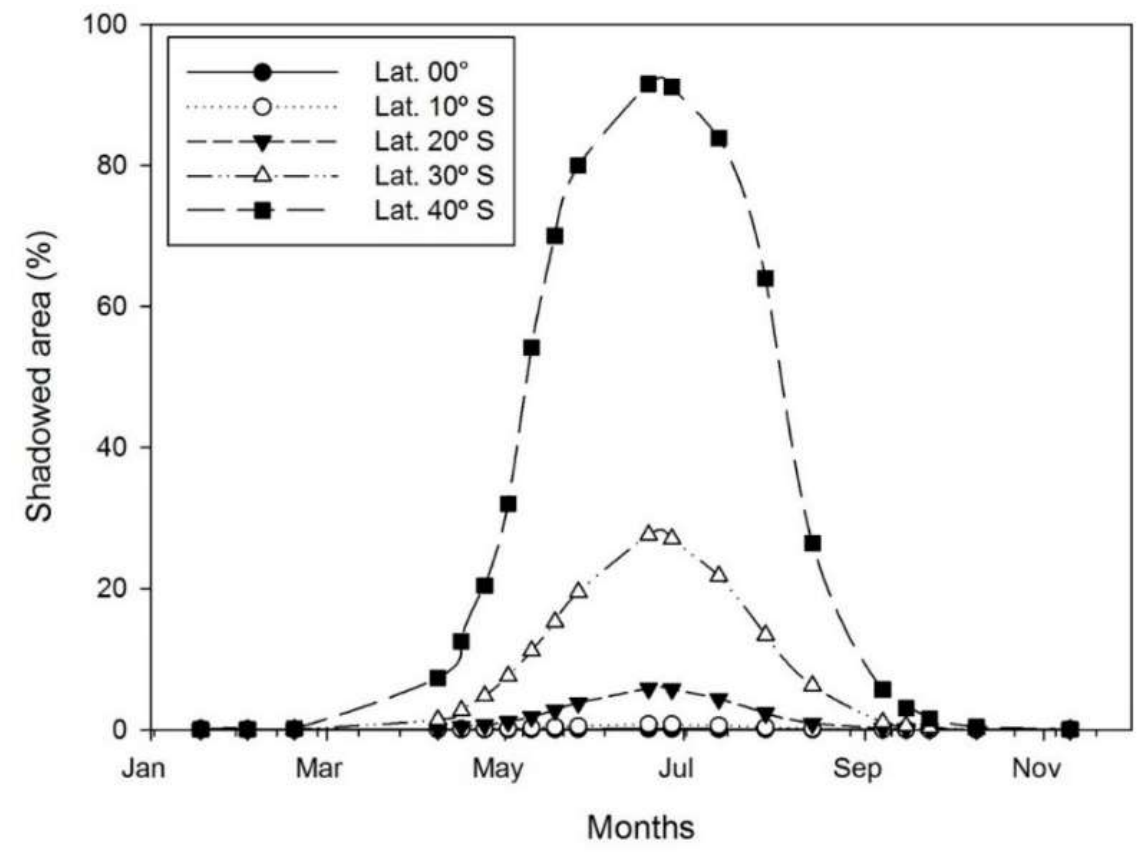

FIGURE 3. Shaded areas on the Southern Hemisphere.

The areas represented by latitudes $0^{\circ}$ and $10^{\circ} \mathrm{S}$, showed minimum shading (Figure 3). This case illustrates that even in the period in which the sun is farthest from the equator, the problem of shading does not have greater importance. Therefore, in these latitudes there is no restriction for acquired satellite images in mountainous areas.

From latitude $20^{\circ} \mathrm{S}$, the largest shadow coverage was found in the period from April to August according to choose the percentage of shadow (Figure 3). In solstice winter Dirtot measured on images ranged from 1.84 to $0.82 \mathrm{MJ} \mathrm{m}^{-2}$. Dirtot's modeling enables us to find that the smallest solar inclination and the effect of scattering caused by the longer trajectory traveled by the sun's rays end up reducing the intensity of incident radiation on the surface and increasing the extension of the shaded area. The Zenithal solar angle was the parameter used to generate the solar radiation models. Proszak-Miąsik \& Rabczak (2017) corroborated with this result by identifying potentials for solar collectors.

Thus, the percentage of the shaded area increased from the smallest to the largest latitudes and latitude $40^{\circ} \mathrm{S}$ configured the smaller Dirtot (only $0.82 \mathrm{MJ} \mathrm{m}^{-2}$ ) from all observed latitudes. At latitude $20^{\circ} \mathrm{S}$, the loss reached at most $8 \%$, at latitude $30^{\circ} \mathrm{S}$ was close to $30 \%$ and at $40^{\circ} \mathrm{S}$ was $91 \%$. The large difference between the range of latitudes $30^{\circ} \mathrm{S}$ and $40^{\circ} \mathrm{S}$ is due to the increased projection of shadows caused by the increase of latitude and in these areas, therefore, ideally, the images should be collected between September and March.

Topographic shadowing changes the surface target spectral answer and can impact the results of studies that use spectral data obtained by sensors on satellites. Holben \& Justice (1980) came to this conclusion by testing the spectral response of nadiral sensors. It was also demonstrated by Wu \& Bauer (2013), using a classification orientated an object in situations of presence and absence of shadow. They concluded that shadow diminishes accuracy, independently of classification method used. In this study, it was possible to verify that in the images with shadows, all classes presented more than $30 \%$ of spectral confusion. These results are according to the ones presented in this paper to ensure the idea that is important to acquire images with the least possible amount of shadow relief.

Concerning the radiation exposure faces and their relationship to Dirtot (Figure 4), the results show that the strands with slopes facing North and East received direct sunlight throughout the analysis period, until latitude $30^{\circ} \mathrm{S}$.

From latitude $20^{\circ} \mathrm{S}$, the choice of images in June and July should be avoided, since these will show changes in the spectral response of surface targets, due to the projection of shadows on the terrain, especially in mountainous areas. In latitude $40^{\circ} \mathrm{S}$, this period covers the months from April to September.

This observation arises from the apparent motion of the Sun throughout the day, occurring from East (sun rising) to the West (sunset), ensuring lighting to the tops of the highest areas, as well as on the slopes with faces pointing to that direction.

Dobre et al. (2014) concluded that solar radiation has a high correlation with the orientation of a terrain face (north, south, east and west) with terrain curvature by comparing the amount of exposed soil after a forest fire. These data agree with this study since these authors also concluded that slopes oriented towards south and west face received lesser amount of solar radiation than the ones oriented to the north. The percentage of topography shadow correlated with aspect surface had its apex during the winter solstice on $40^{\circ} \mathrm{S}$ latitude (Figure 4). 

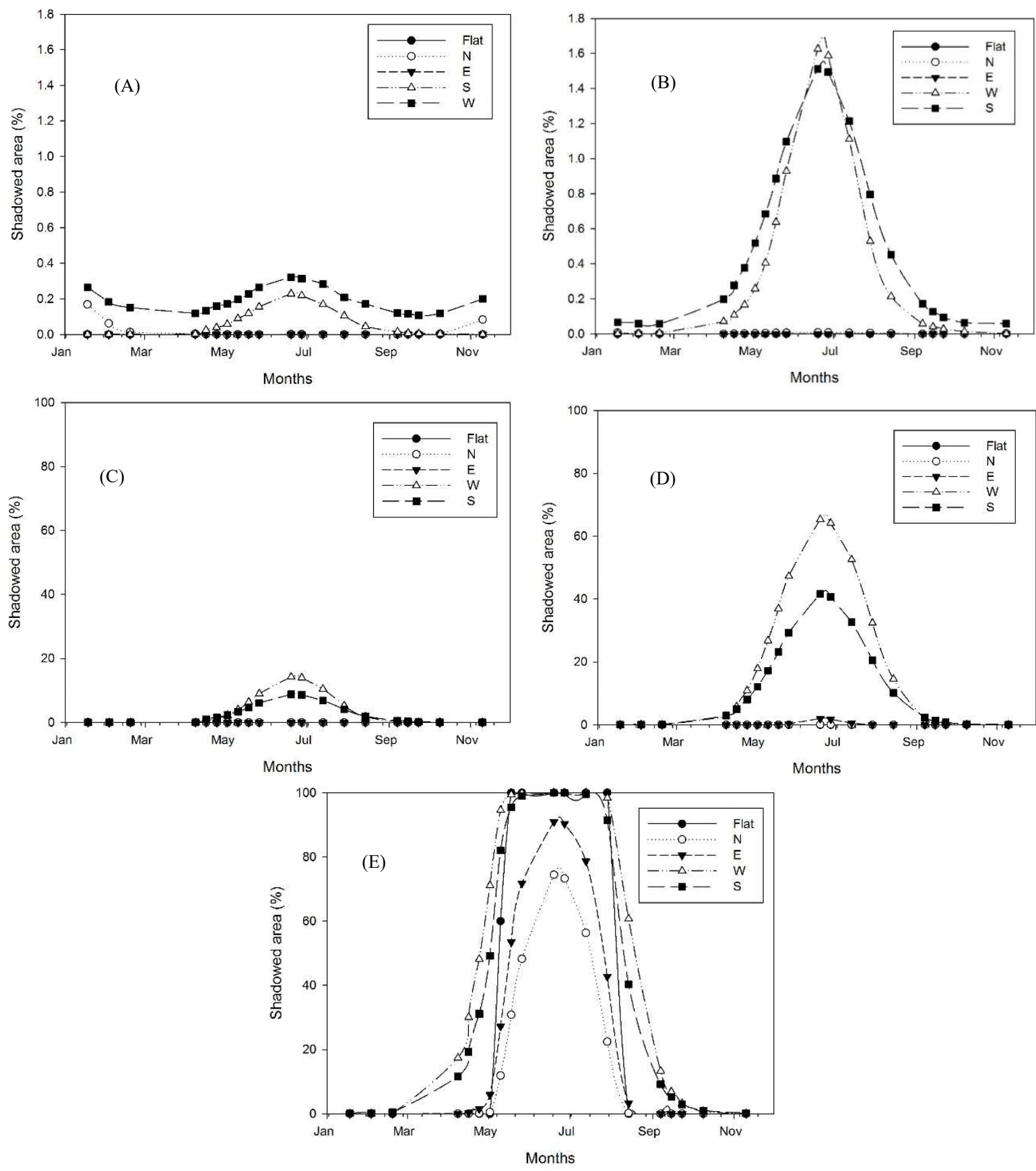

FIGURE 4. Dirtot distribution by the orientation of the relief faces in latitudes assessed: (A) $0^{\circ}$; (B) $10^{\circ} \mathrm{S}$; (C) $20^{\circ} \mathrm{S}$; (D) $30^{\circ} \mathrm{S}$ and $\mathrm{E} 40^{\circ} \mathrm{S}$. Flat; $\mathrm{N}=$ North; $\mathrm{E}=$ East; $\mathrm{S}=$ South and $\mathrm{W}=$ West.

The aspect towards the South and West faces showed increasing shading levels, as it gets far from the Equator's line. It is believed that these results originate mainly from the time the satellite makes the imaging of the scenes, around 10:00 AM. Ferreira et al., (2012), also obtained this same result when, throughout the year, the slopes of the mountains with the exposure facing South received lower incidence of direct solar radiation, remaining shaded for an extended period along the year. And on the other hand, the slopes of the mountains facing North received throughout the year a higher incidence of Dirtot.

In high latitudes, the solar elevation angle decreases, causing that hills and mountains present on the terrain to show the East face lightened and the West face shaded at the same time on the satellite passage. Therefore, this places can be an important major source of error in estimating surface reflectance (Li et al., 2012; Adeline et al., 2013). This problem could be minimized if the time of the satellite passage would be approached at 12:00 AM local time, thus maximizing the solar elevation angle since, at this time the Sun is at the zenith, and then there is no projection of shadows.

Overall, until latitude $10^{\circ} \mathrm{S}$ (Figure $4 \mathrm{~A}$ and $\mathrm{B}$ ), the shading caused by the relief was less than $2 \%$ and can be neglected. For latitude $20^{\circ} \mathrm{S}$ (Figure $4 \mathrm{C}$ ), the shading in July reached $14 \%$ on the slopes facing South, evolving to $65 \%$ at latitude $30^{\circ} \mathrm{S}$ (Figure $4 \mathrm{D}$ ) and $100 \%$ at latitude $40^{\circ} \mathrm{S}$ (Figure $4 \mathrm{E}$ ). 
Analyzing all twenty images of Landsat TM and ETM+ satellite of the year 2011 available on the database of USGS, considering up to $10 \%$ of topography shadow on the scene, it might be observed that until latitude $10^{\circ} \mathrm{S}$ images can be obtained throughout the year. For latitude $20^{\circ} \mathrm{S}$, the ideal period for image collection extends from September to May, and eleven images may be collected, from the twenty available in the period. At latitude $30^{\circ} \mathrm{S}$, this period ranged from September to March, resulting in the collection of eight images. For latitude of $40^{\circ} \mathrm{S}$, there was a considerable reduction in the number of images available, only five remaining with less shading effect.

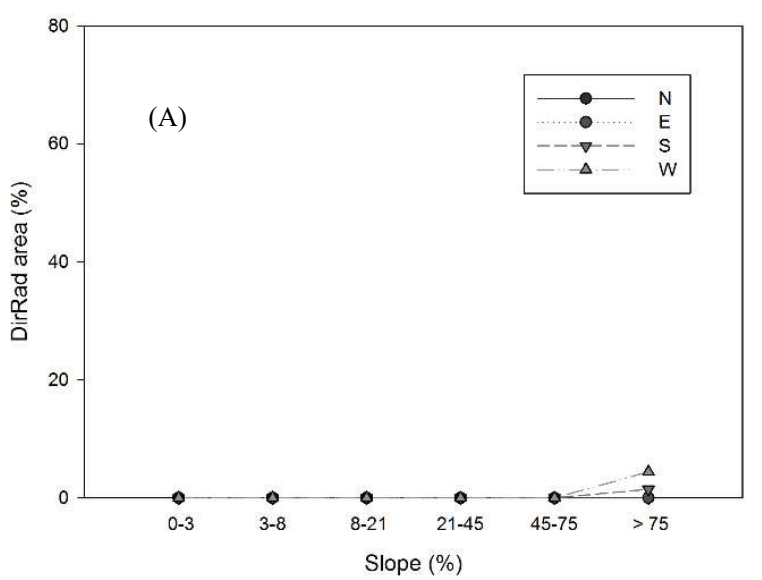

The amount of solar lighting on the terrain is crucial for Remote Sensing products, being important to identify the best season for obtaining images, mainly in the high latitudes that show rugged relief. Thinking about this problem Schaepman-Strub et al., (2006) compared the two hemispheres and the zenith angle and found major discrepancies in the amount of solar lighting in short intervals of wavelength, corresponding to the visible and near-infrared bands, showing differences in direct and diffuse lighting conditions on the terrain.

The shading values (Figure 5) taking into account simultaneously the face exposure and declivity variables showed that there had been the greater amount of shadows in slopes exceeding $45 \%$.
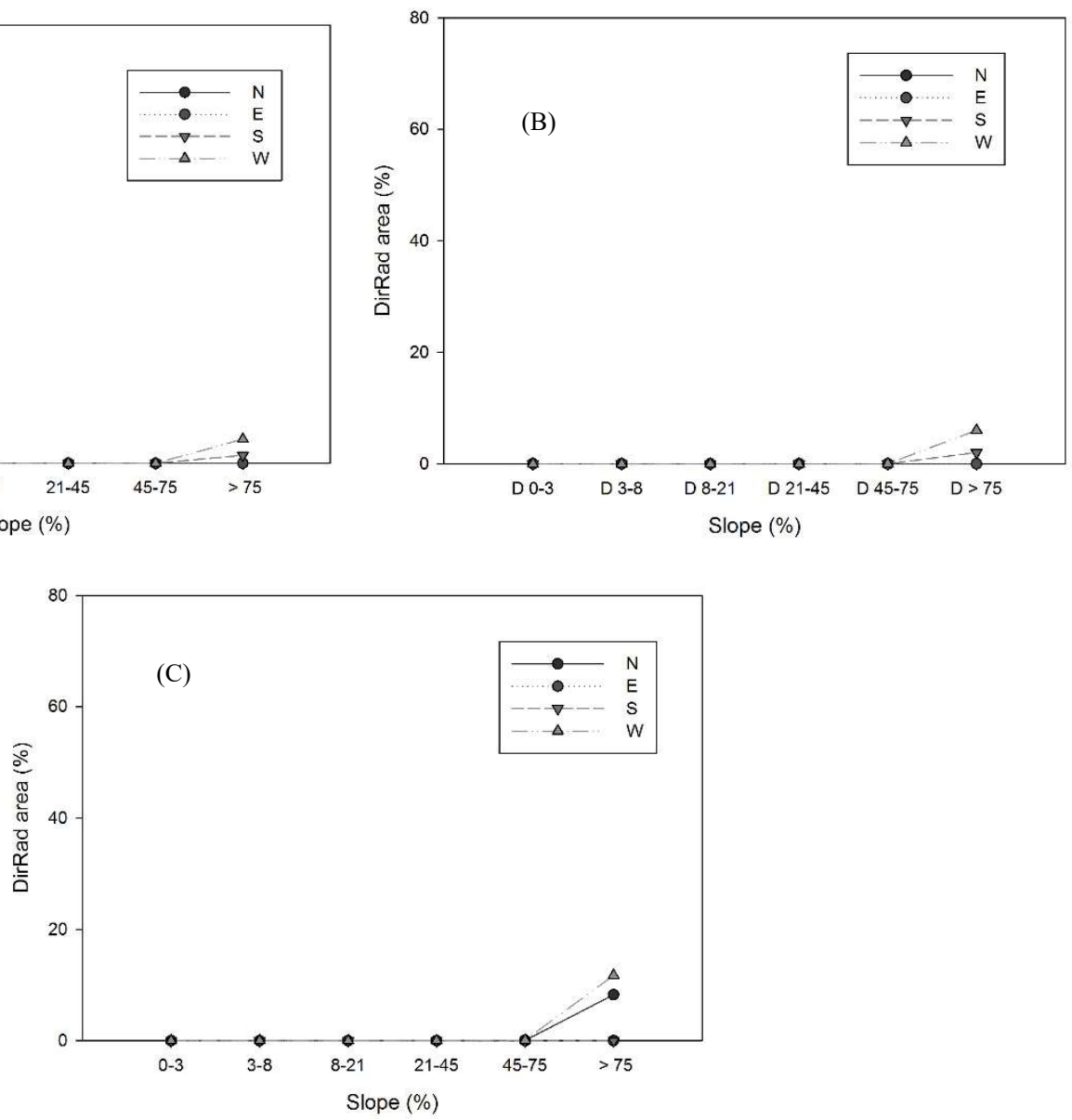

FIGURE 5. (A, B, C). Evolution of shading by exposure faces and slope in approximate dates to the solstices and equinoxes. $\mathrm{A}, \mathrm{B}$ and $\mathrm{C}=$ January $18^{\text {th }}$ at latitudes $0^{\circ}, 20^{\circ} \mathrm{S}$ and $40^{\circ} \mathrm{S}$, respectively; $\mathrm{N}=$ North; $\mathrm{E}=$ East; $\mathrm{S}=\mathrm{South}$ and $\mathrm{W}=\mathrm{West}$.

These areas are located on the slopes facing South and West (Figure 5) The results corroborate with Honkavaara et al. (2012) study which stated that the amount of solar lighting in mountainous regions is a deciding factor for various applications in Remote Sensing. On January $18^{\text {th }}$ image, after the summer solstice, at latitudes $0^{\circ}, 20^{\circ} \mathrm{S}$ and $40^{\circ} \mathrm{S}$ (Figure $5 \mathrm{~A}, \mathrm{~B}, \mathrm{C}$ ), the percentage of the shaded area was low in all latitudes, slope classes and radiation exposure face.
In a date close to the Autumn Equinox, April $08^{\text {th }}$ (Figure 5 D, E, F), the most significant loss of information by shadows was at Latitude $40^{\circ} \mathrm{S}$ (Figure $5 \mathrm{~F}$ ), reaching the maximum of $77 \%$ on the South face and $68 \%$ on the West face, both for the strong wavy and rugged declivities, respectively. The projection of shadows for the South and West sides began to be more concentrated, due to the departure of the Sun to the Northern Hemisphere, starting to include less steep slopes, such as those of class $8-21 \%$. 

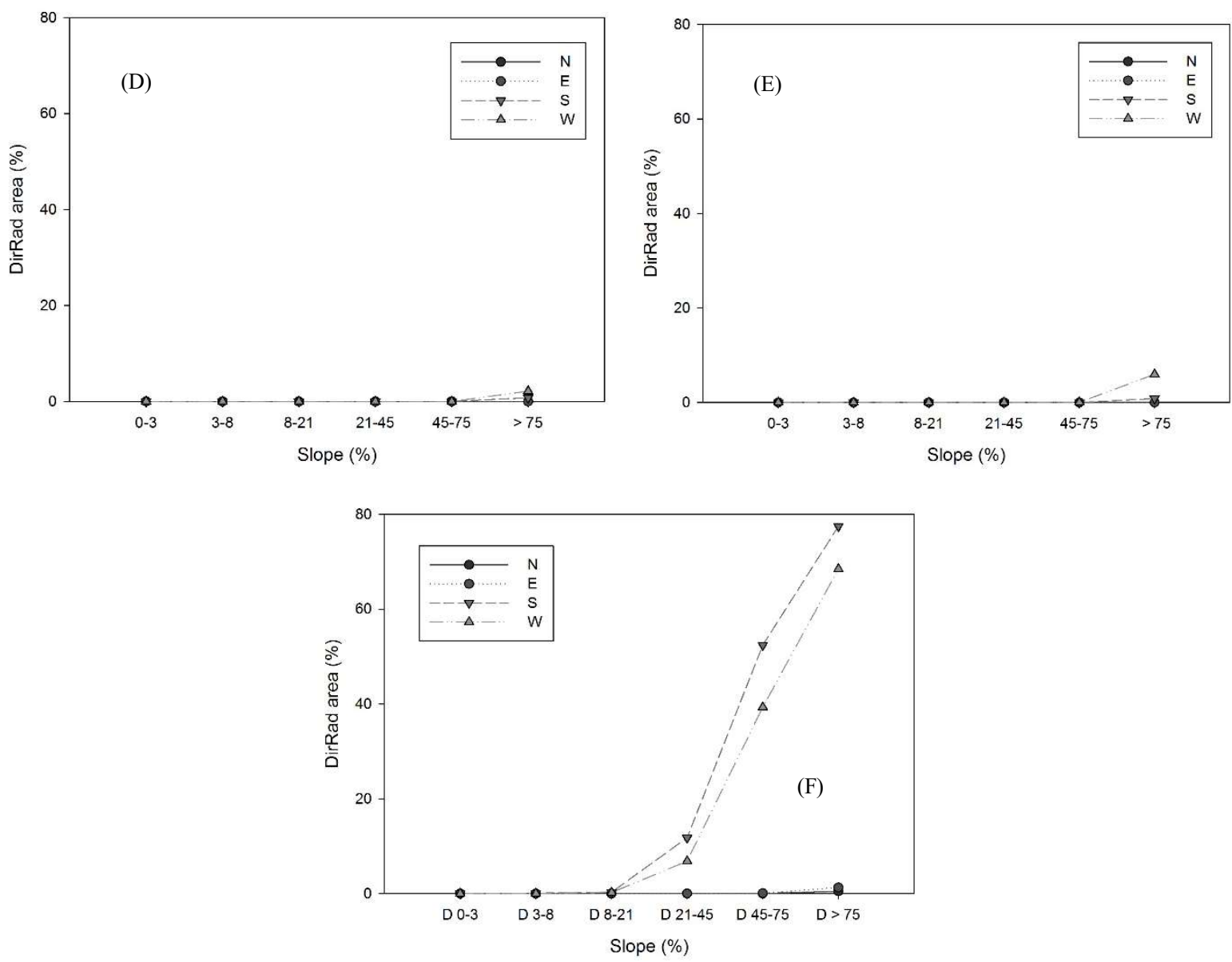

FIGURE 5. (D, E, F). Evolution of shading by exposure faces and slope in approximated dates to solstices and equinoxes. D, E and $\mathrm{F}=$ April $08^{\text {th }}$ at latitudes $0^{\circ}, 20^{\circ}$ and $40^{\circ} \mathrm{S}$, respectively; $\mathrm{N}=$ North; $\mathrm{E}=$ East; $\mathrm{S}=$ South and $\mathrm{W}=$ West.

The month of June was characterized by the more severe situation regards shading in the Southern Hemisphere, due to the winter solstice. In this circumstance, the sun is at its peak distance. Coupled with the low luminosity, there is a favoring in the increase of shadows during this period, which was shown with a greater projection since the rays are hitting the terrain obliquely. The study demonstrated by Swift Jr \& Knoerr (1973) showed with data measured in the field that the winter solstice presented less than solar radiation incident on mountainous areas as the radiation index.

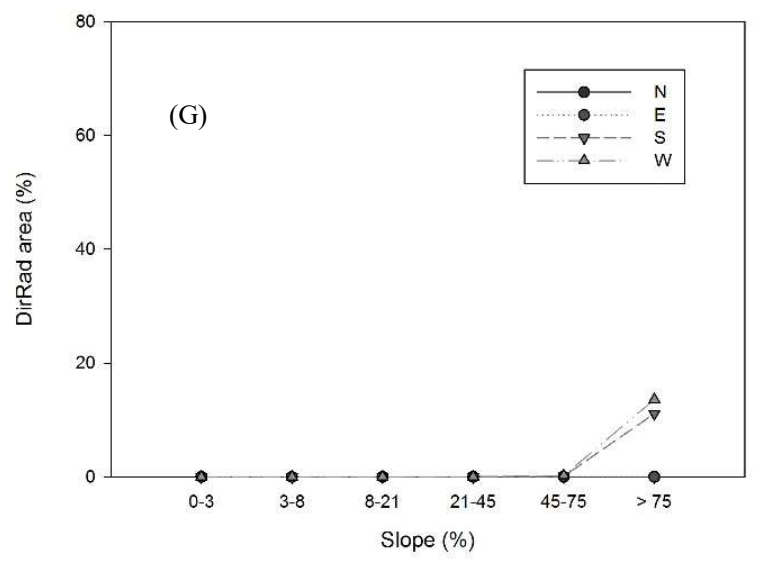

Therefore, for the image of 06/19/2011 (Figure 5 $\mathrm{G}, \mathrm{H}, \mathrm{I}$ ), the only area in which there was no significant loss by shading was in the Equator. At latitudes $20^{\circ} \mathrm{S}$ and $40^{\circ} \mathrm{S}$, there has been a greater projection of shadows in the image and, consequently, greater loss of spectral information of targets on the terrain. However, the shading at latitude $40^{\circ} \mathrm{S}$ (Figure $5 \mathrm{I}$ ) constituted the scenario with the largest loss, since all relief's exposure faces had a maximum shadowing in all the slopes.

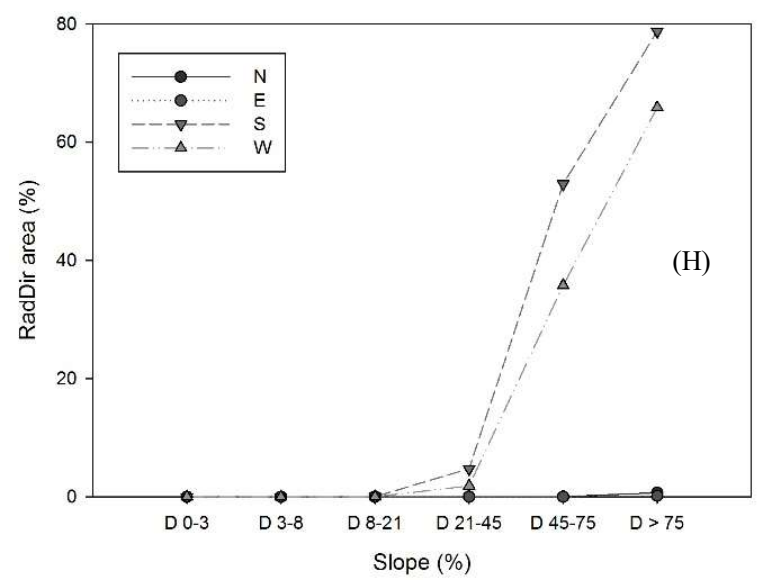




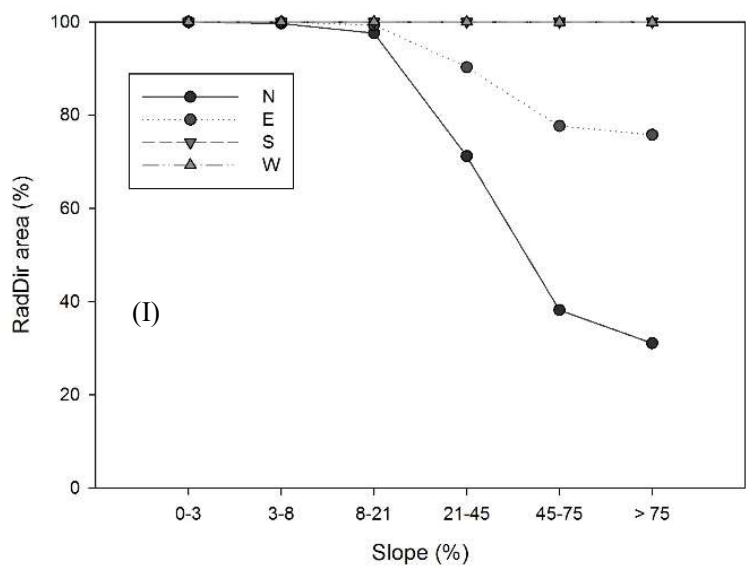

FIGURE 5. (G, H, I). Evolution of shading by exposure faces and slope in approximated dates to solstices and equinoxes. G, H and $\mathrm{I}=$ June, $19^{\text {th }}$ at latitudes $0^{\circ}, 20^{\circ} \mathrm{S}$ and $40^{\circ} \mathrm{S}$, respectively; $\mathrm{N}=$ North; $\mathrm{E}=$ East; $\mathrm{S}=$ South and $\mathrm{W}=\mathrm{West}$.

During the Spring equinox in the Southern Hemisphere (Figure $5 \mathrm{~J}, \mathrm{~K}, \mathrm{~L}$ ), when days and nights have the same duration, a little occurrence of shaded areas in the Equator and at latitude $20^{\circ} \mathrm{S}$ is found. However, at latitude $40^{\circ} \mathrm{S}$ (Figure $5 \mathrm{~L}$ ) there was a $45 \%$ and $49 \%$ topography

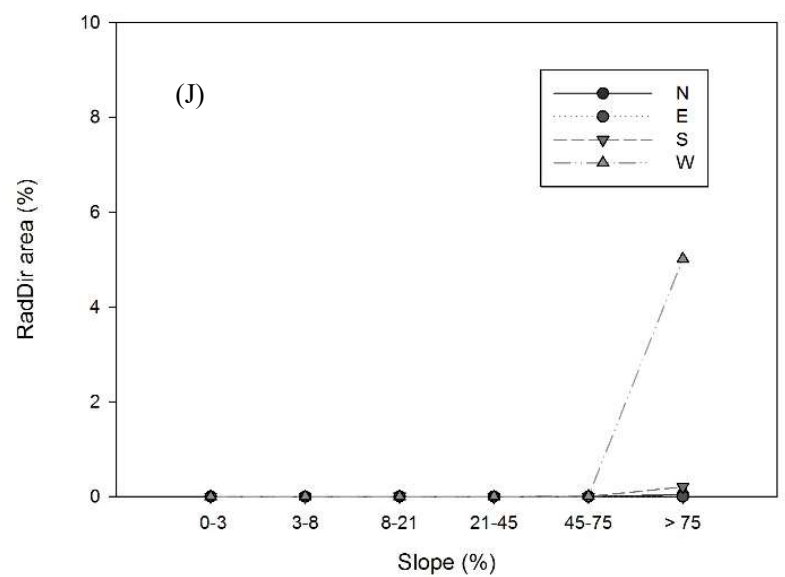

shadow on South and West faces, respectively, for the slopes bigger than $75 \%$. Data analysis demonstrated that for this latitude, faces with higher declivity have their south and west slopes shaded and Dirtot is available for lesser declivities.

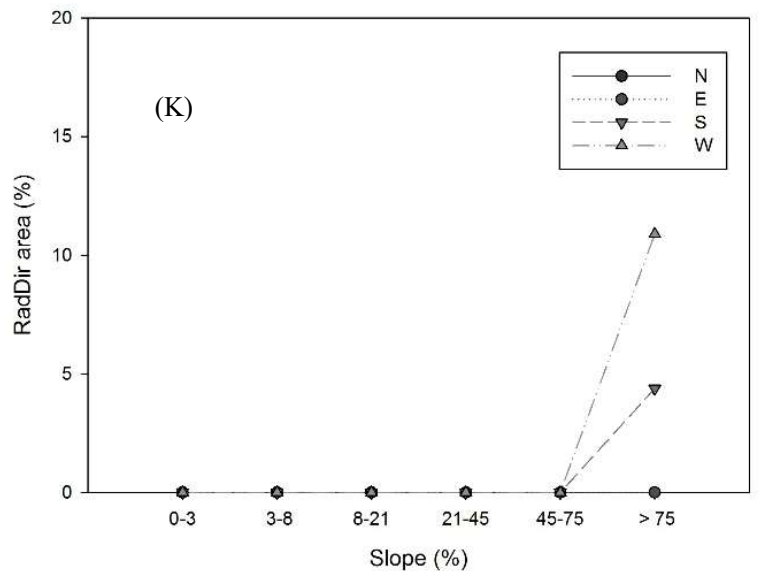

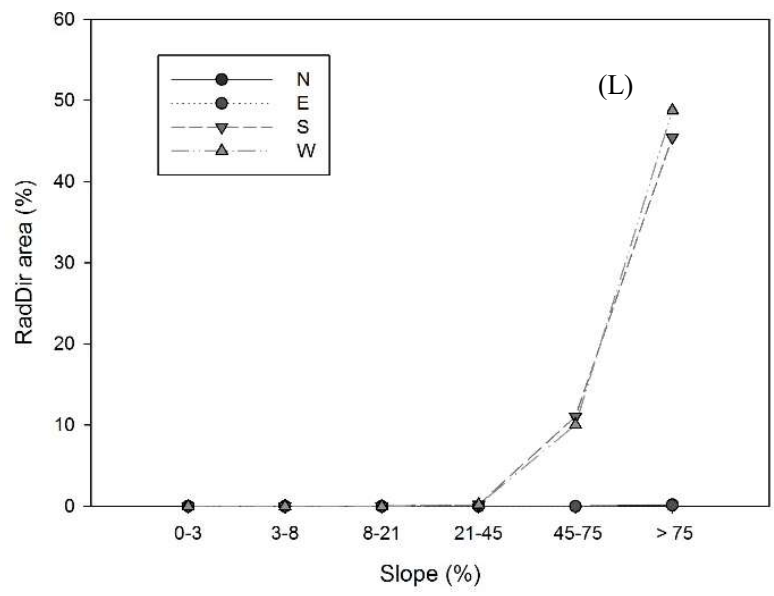

FIGURE 5. (J, K, L). Evolution of shading by aspect faces and slope in approximated dates to solstices and equinoxes. J, K and $\mathrm{L}=$ September $23^{\text {rd }}$ at latitudes $0,20^{\circ} \mathrm{S}$ and $40^{\circ} \mathrm{S}$, respectively; $\mathrm{N}=$ North; $\mathrm{E}=\mathrm{East} ; \mathrm{S}=$ South and $\mathrm{W}=\mathrm{West}$. 
When choosing a scene, the user must take into account the slope of the area. Whether the scene shows mountainous or rugged reliefs, it should stick to the recommended months presented here aiming to lose as low as possible information of spectral targets, mainly in the South and West faces. Also, this study has yet a potential to help users of remote sensing products like harvest forecast, water resources management, and agrometeorology, among others by indicating the best season to scene acquisition.

\section{CONCLUSIONS}

This study has a potential use on help choosing images to use on image classification as well as on harvest forecast modeling from the period indication of its acquisition.

Radiation modeling has been demonstrated effective for analysis comparing the same area varying only its latitude. It propitiates suitable conditions for comparisons because even if we had used different areas, the changes would be on patterns of relief, amount of slopes and this would implicate in a not trustable result. For future studies would be recommended to use solar radiation acquired infield to check model efficiency.

\section{ACKNOWLEDGMENTS}

The first author would like to thank National Council of Scientific and Technologic Development (CNPq) and Soil Department of Federal University of Viçosa for financial support and scholarship granted.

\section{REFERENCES}

Adeline KRM, Chen M, Briottet X, Pang SK, Paparoditis N (2013) Shadow detection in very high spatial resolution aerial images: a comparative study. ISPRS Journal of Photogrammetry and Remote Sensing 80:21-38.

Balthazar V, Vanacker V, Lambin EF (2012) Evaluation and parameterization of ATCOR3 topographic correction method for forest cover mapping in moun-tain areas. International Journal of Applied Earth Observation and Geoinformation 18:436-450.

DOI: http://dx.doi.org/10.1016/j.jag.2012.03.010

Burrough PA, McDonnell RA (1998) Principles of geographical information systems. New York, Oxford University Press, 34p.

Chance CM, Hermosilla T, Coops NC, Wulder MA, White JC (2016) Effect of topographic correction on forest change detection using spectral trend analysis of Landsat pixel-based composites, International Journal of Applied Earth Observation and Geoinformation 44:186-194. DOI: https://doi.org/10.1016/j.jag.2015.09.003

Dobre M, Wu JQ, Elliot WJ, Miller IS, Jain, TB (2014) Effects of topographic features on postfire exposed mineral soil in small watersheds. Forest Science 60(6):1060-1067.

Ediriweera S, Pathirana S, Danaher T, Nichols D, Moffiet T (2013) Evaluation of Different Topographic Corrections for Landsat TM Data by Prediction of Foliage Projective Cover (FPC) in Topographically Complex Landscapes.

Remote Sensing 5:6767-6789.

DOI: http://dx.doi.org/10.3390/rs5126767
EMBRAPA - Empresa Brasileira de Pesquisa Agropecuária: Serviço Nacional de Levantamento e Conservação do Solo (1999) Súmula da X Reunião Técnica de Levantamento de Solos. Rio de Janeiro.

ESRI - Environmental Systems Research Institute (2011) ArcGIS Professional GIS for the desktop, versão 10.1 CA.

Farr TG, Kobrick M (2000) Shuttle Radar Topography Mission produces a wealth of data. American Geophysical Union 81(4):583-585.

Filippi AM, Güneralp I (2013) Influence of shadow removal on image classification in riverine environments. Optics letters 38:1676-8. DOI:

http://dx.doi.org/10.1364/OL.38.001676

França MM, Fernandes Filho EI, Ferreira WPM, Soares VP, Lani JL (2014) Effect of relief shading and variation of latitude in the selection of Landsat TM and ETM +. In: ASABE Annual International Meeting. Montreal, ASABE Meeting Presentation, Proceedings...

Ferreira WPM, Ribeiro MF, Fernandes Filho EI, Souza CF, Castro CCR (2012) As características térmicas das faces noruega e soalheira como fatores determinantes do clima para a cafeicultura de montanha. Brasília, DF, Embrapa.

Gao BC, Montes MJ, Davis CO, Goetz AFH (2009) Atmospheric correction algorithms for hyperspectral remote sensing data of land and ocean. Remote Sensing of Environment 113(1):17-24. DOI:

http://dx.doi.org/10.1016/j.rse.2007.12.015

Goyens C, Jamet C, Schroeder T (2013) Evaluation of four atmospheric correction algorithms for Modis-Acqua images over contrasted coastal waters. Remote Sensing of Environment 131:63-75. DOI:

http://dx.doi.org/10.1016/j.rse.2007.12.015

Hantson S, Chuvieco E (2011) Evaluation of different topographic correction methods for Landsat imagery. International Journal of Applied Earth Observation and Geoinformation 13:691-700. DOI: http://dx.doi.org/10.1016/j.jag.2011.05.001

Holben BN, Justice CO (1980) The topographic effect on spectral response from nadir-pointing sensors. Photogrammetry Engineering and Remote Sensing 46(9):1191-1200.

Honkavaara E, Markelin L, Rosnell T, Nurminen K (2012) Influence of solar elevation in radiometric and geometric performance of multispectral photogrammetry. ISPRS Journal of Photogrammetry and Remote Sensing 67:13-26. DOI: http://dx.doi.org/10.1016/j.isprsjprs.2011.10.001

Hutchinson MF (1989) A new procedure for gridding elevation and stream line data with automatic removal of spurious pits. Journal of Hydrology 106:211-232.

Hutchinson MF, Stein JA, Stein JL, Xu T (2009) Locally adaptive gridding of noisy high resolution topographic data. 18th World IMACS / MODSIM Congress. Cairns, Proceedings ...

Jarvis A, Reuter HI, Nelson A, Guevara E (2008) Holefilled SRTM for the globe Version 4. Enschede, University of Twente. 
Koudouris G, Dimitriadis P, Iliopoulou T, Mamassis N, Koutsoyiannis D (2017) Investigation on the stochastic nature of the solar radiation process. Energy Procedia 125:398-404. DOI:

https://doi.org/10.1016/j.egypro.2017.08.076

Lambin EF, Meyfroidt P (2011) Global land use change, economic globalization, and the looming land scarcity. Proceedings of the National Academy of Sciences of the United States of America 108:3465-4347. DOI: http://dx.doi.org/10.1073/pnas.1100480108

Li F, Jupp DLB, Thankappan M, Lymburner L, Mueller N, Lewis A, Held A (2012) A physics-based atmospheric and BRDF correction for Landsat data over mountainous terrain, Remote Sensing of Environment 124:756-770. ISSN 0034-4257, DOI: https://doi.org/10.1016/j.rse.2012.06.018

López G, Batlles FJ, Rossi F (2014) Deriving Solar Radiation in a Mountain Area from MODIS Information. Energy Procedia 57:1092-1099. DOI: https://doi.org/10.1016/j.egypro.2014.10.095

USGS - United States Geological Survey (1988)

LANDSAT Thematic Mapper. Reston, USGS Global

Visualization Viewer. Satellite image 20110531 bands1-7. Scale 1:100.000.

Movia A, Beinat A, Crosilla F (2016) Shadow detection and removal in RGB VHR images for land use unsupervised classification. ISPRS Journal of Photogrammetry and Remote Sensing 19:485-495.

Ponzoni FJ (2016) Impact of topographic correction on soil and vegetation cover spectral characterization by TM/Landsat 5 imagery. CERNE 22(3):289-298.

Proszak-Miąsik D, Rabczak S (2017) Impact of solar radiation change on the collector efficiently. Journal of Ecological Engineering 18(1):268-272. DOI: https://doi.org/10.12911/22998993/67106

Rich PM (1990) Characterizing plant canopies with hemispherical photography. In: Goel NS and Norman JM (eds). Instrumentation for studying vegetation canopies for remote sensing in optical and thermal infrared regions. Remote Sensing Reviews 5:13-29.

Rich PM, Dubayah R, Hetrick WA, Saving SC (1994) Using viewshed models to calculate intercepted solar radiation: applications in ecology. American Society for Photogrammetry and Remote Sensing Technical Papers 524-529.
Rich PM, Fu P (2000) Enlightenment for modeling systems - Models looking up for answers. Resource Magazine.

Sanin A, Sanderson C, Lovell BC (2012) Shadow detection: a survey and comparative evaluation of recent methods. Pattern Recognition 45(4):1684-1695.

Schaepman-Strub G, Schaepman M E, Painter TH, Dangel S, Martonchik JC (2006) Reflectance quantities in optical remote sensing - definitions and case studies. Remote Sensing of Environment 103(1):27-42. DOI: http://dx.doi.org/10.1016/j.rse.2006.03.002

Schanmugan C (2012) CAAS: Atmospheric Correct Algorithm for the Remote Sensing of Complex Waters. Annales Geophisicae 30:203-220. DOI: http://dx.doi.org/10.5194/angeo-30203-2012

Shulmann T, Katurji M, Zawar-Reza P (2015) Seeing through shadow: Modelling surface irradiance for topographic correction of Landsat ETM+ data. ISPRS Journal of Photogrammetry and Remote Sensing 99:14-24. DOI: https://doi.org/10.1016/j.isprsjprs.2014.10.004

Swift Jr LW, Knoerr KR (1973) Estimating solar radiation on mountain slopes. Agricultural Meteorology 12:329-336.

Valeriano MM (2004) Modelo digital de elevação com dados SRTM disponíveis para a América do Sul. Instituto Nacional de Pesquisas Espaciais.

Vanonckelen S, Lhermitte S, Rompaey AV (2013) The effect of atmosphericand topographic correction methods on land cover classification accuracy. International Journal of Applied Earth Observation and Geoinformation 24:921. DOI: http://dx.doi.org/10.1016/j.jag.2013.02.003

Wu J, Bauer M E (2013) Evaluating the Effects of Shadow Detection on QuickBird Image Classification and Spectroradiometric Restoration. Remote Sensing 5:44504469. DOI: http://dx.doi.org/ 10.3390/rs5094450

Zhang Y, Yan G, Bai Y (2015) Sensitivity of Topographic Correction to the DEM Spatial Scale. IEEE Geoscience and Remote Sensing Letters 12:53-57. 